\title{
Divorce in the Side of a Marriage Counselling Values
}

\author{
Tonny Andrean, David Ming, and Novita Loma Sahertian
}

\section{ABSTRACT}

\begin{abstract}
At the annual conference of The American Psychiatric Association (APA) in Miami, there was a workshop entitled "Family Crisis". The results of a study said that in the last 30 years, $60 \%$ of families in the United States ended in divorce, and $70 \%$ of their children did not develop well, behave deviant or antisocial. For example, seen juvenile delinquency, abuse of NAZA (Narcotics, Alcohol, and other Addictive Substances), promiscuity, deviant sexual behavior and so on. It was also stated that divorce rates are increasing, marriages are decreasing because many people choose to live together without marriage or single life and free sex. Disloyalty (abuse) among families in the US turned out not to be the monopoly of husbands alone, but $40 \%$ of the wives there were also involved in affair with third parties. Of the five marriages in the first five years, three divorces occurred. The author gives the purpose of writing to discuss the crisis in the household, rebuild the household and give Christian values in counteracting divorce. The author uses descriptive literature research method data and provides research results: How a harmonious family can be established dynamically if we base our family building on the basis of strong Christian spirituality values accompanied by a fabric of good communication between us and our children. Surprisingly few studies have explored the implications of divorce happened because family can not be established, especially in young adulthood. This study addresses several theoretical arguments linking divorce in the side of spiritual value with reduced religious involvement in young adulthood and tests relevant hypotheses using data from a unique sample. Results show that divorce in the side of spiritual value is associated with substantially lower communicate religious involvement among young adults in their families house.
\end{abstract}

Keywords: divorce, marriage, value, spirituality

\section{DISCUSSION}

In Washington D.C. at the annual conference of The American Association (APA), there was a workshop entitled "Generation in Jeopardy". In the workshop, it was described how the sexual behavior of adolescents in the US was very worrying, especially the spread of AIDS venereal disease.

Firstly, Statistics indicate that promiscuity among US adolescents is very worrying: First, 10 out of 7 teenage girls and 8 teenage boys have become one another doing promiscuity.

Second, young women are more aggressive and assertive, namely one young woman hanging out freely with her 4 male friends.

Third, every minute there are 2 pregnant teenagers, teenage pregnancy reaches $40 \%$ of all national pregnancies, of 3 births one of them out of wedlock. The result 1,200,000 extramarital pregnancies were recorded and only half of them were aborted.

Fourth, the spread of venereal disease among US adolescents is increasing, especially AIDS. Every minute 3
Published Online: February 24, 2021

ISSN: $2684-446 \mathrm{X}$

DOI : 10.24018/ejtheology.2021.1.1.1

Tonny Andrean

Charisma Theological College, Bandung, INDONESIA

(e-mail: ta.restoration153@ gmail.com) David Ming

Abdi Gusti Theological Seminary, Nganjuk, INDONESIA

(e-mail: david@sttabdigusti.ac.id)

Novita Loma Sahertian

Institute Christian Education, Ambon, INDONESIA

(e-mail: vitasahertian@ gmail.com) people get the HIV virus that causes AIDS. ${ }^{1}$ Today AIDS is the number one killer among teenagers and young people (Dr. Harold Jaffe, 1994). Another prediction says that in 2000, AIDS was the number one killer over heart disease. ${ }^{2}$

Fifth, even though teenagers have been given sex education in schools and are taught how to prevent pregnancy and venereal disease, it turns out that sex education is backfired, venereal disease is increasing and more and more extramarital pregnancy. The evaluation results showed that $74 \%$ of them did not use condoms and other contraceptives, $65 \%$ had anal sex.

What about the case in Indonesia? Also very alarming is the setback that befalls teenagers, meaning: the increasing number of those who smoke, use drugs, commit sexual and pornographic violations, fight and so on. The data is quite alarming for example according to the Social Economic survey: in $23 \%$ of the population aged 10 years and over have smoking habits. ${ }^{3}$

More than 50\% start at the age of 15-19 years. Also in 1998 the results of a survey by the Institute for Overcoming Smoking Problems stated that $59 \%$ of men and $4.8 \%$ of women aged 10 years and over were "now smokers", a 
minimum of one day for at least 3 months. ${ }^{4}$

Smoking is one of the doors to becoming a drug user.

Most of the narcotics users are smokers. At present in Indonesia, there are at least 5 million narcotics addicts, of which $70 \%$ are 14-15 years old. An increase in the number of patients was also seen from users with the number of patients being treated in drug addiction hospitals for example: there were 1,500 patients, increase to 3,500 , up to 5,847 , more 9,852 and there were 7,512 patients. $^{5}$

The abuse of narcotics and psychotropic drugs has reached teenagers up to the villages and into economically weak groups.

In addition to the above problems, teenagers also range from sexual and pornographic violations, in addition to being victims of rape. In a student rasia to capture narcotics users and dealers also found condoms, VCD pornographic images. The increase in narcotics use and sexual violations significantly affected the number of HIV / AIDS addicts reaching 7 people.

Also about student fights just increased in quality and quantity. According to Kompas ${ }^{6}$, in Jakarta alone recorded 93 cases, up to 230 cases, and the victims of brawl became 26 cases, 56 were seriously injured and 103 were injured by adolescents. And according to a survey of the Research and Development Institute for Narcotics and Young Generation Problems in Indonesia, it is known that out of 100 brawl cases there have been contracted drugs.

Prof. Dr. Fawzia Aswin, professor of the Faculty of Psychology UI, said that Metro Jaya Police Data showed 193 cases of student brawl occurred in 257 schools in Jakarta. Meaning the average student brawl in the capital every 2 days of brawl, resulting in 35 students killed, 204 others injured and 478 vehicles damaged. ${ }^{7}$

From the example above, if the community is permissive with the pretext of "freedom" and human rights, or what are the reasons for letting the lifestyle continue, then it can already be imagined how the shape or structure of the family in the future? Then, is there a form of family as we follow today? Which in turn the use of science and technology without IMTAK not bring prosperity, but the destruction of a social order, family. Didn't the Einstein scholar say, "Science without religion is blind, and religion without science is paralyzed?"

\section{BASIC THEORY}

"Experience is the best teacher." Thus the saying goes. What is being experienced by families in the West whose existence on the brink of crisis should be an example for our society. The family is the smallest unit of society while society is part of the nation. The family is the basis of a strong nation. Therefore, a family crisis will result in the disintegration and disorganization of the family itself as the smallest order in society. If a family form is not good it is impossible for other parents to be good and will not achieve real happiness. If this is sustainable and more and more families will also experience a crisis, it will have an impact on the disintegration and disorganization of the social fabric of society, which in turn will lead to national and state social arrangements.

Referring to the Word of God, believers must choose to marry, not choose to live together without marriage, not single life by changing partners, not promiscuity, not living in pairs with the same, not living a prostitute, or other forms of marriage. Likewise children should be the children of a legal marriage. Research shows that the development of children resulting from extramarital relations will not develop properly and the risk of deviant behavior is greater than children born to parents who are legally married.

For example, modern countries and industries that are secular (Western) in their families have a crisis. This is due to modern societies and secular-style industries that occur fundamentally uncertainty in the fields of law, norms, morals, values, and ethics of life, including the ethical and moral life of the relationship between men and women.

\section{RESULT AND DISCUSSION}

\section{A. Return to Family}

In the United States the awareness to return to the family began, beginning with the founding of the Mother at Home Foundation, which was founded by a group of women who are concerned about the fact that more and more mothers are working outside the home. In addition, it was felt in the results of a study of 2000 American children, which showed a tendency to decline in basic emotional and social skills. They become more restless, irritable, more depressed, lackluster, more depressed and lonely, more demoralizing and disobedient, and so on.

The foundation, which just stood at a time of only 700 people, has now reached tens of thousands of people. This invites mothers to work inside the home, educate and care for their families. Here it is emphasized that a family has a biological function (only the place of birth), an effective function (place of affection), and a function of socialization (a place to form a child's personality).

But with the current of urbanization, the widening of individualism, the spread of social emancipation of women, the existence of birth restrictions, the development of material culture, the rapid discovery and innovation of technology, the improvement of telecommunications-transportation facilities and the expansion of industrialization, making the above family functions gradually change.

William F. Osburn (The Changing Family, 1910) shows a picture in the statistical presentation that family activities in this case are caused by the economy, transportation, recreation or entertainment, education and religion not shifting rapidly to institutions outside the family. The family is increasingly changing from a production unit to a consumption unit. The task of educating teenagers is left to schools and the community. The task of protecting children is left to the baby siter, domestic servants, even to day care centers until the task of entertaining children is left to the television, playstation, VCD and others.

Back to the family is the best solution that is very effective to reduce the various depravities that exist in society. Because in the family stored a very extraordinary potential and the role of parents is very dominant in optimizing that potential. In fact, parents are the first and foremost for children.

God made us parents to build the lives of children through conversation communication that is very beneficial in building the nature of children. As parents we have to cultivate the habit of talking with children is two-way communication. The task of parents is not just to supervise but to serve the hopes of developing children for the glory of God. Building life is not a separate part of the task of being a 
parent, but something a parent must do is a part and process of building children's lives, because the main goal is to save the lives of these children. ${ }^{8}$

\section{B. Communication as a Foundation for Dynamic Friendship}

This communication is a personal-to-personal conversation that really helps children find their true identity, because they immediately feel the dialogue with parents. So, the family does not eliminate the gap of children and parents. Children feel safe, can develop a healthy identity and not asosisal.

Here communication is the basis of our friendship with our children. This means, communication is not just talking to one another, but it means capturing ideas better than talking. Communication is a conversation between two individuals who are involved with each other and not only talk about external matters but share with one another. Communication also means accepting each other's existence. In other words, communication can be interpreted as a quality conversation, mutual build, fill, divide so that between two or more individuals who are communicating can foster a close and intimate relationship even friendships that always develop. ${ }^{9}$

\section{Commitments}

To foster good communication between families and their children requires firm family commitment. Family commitment to their children means that there is family recognition of their children, "you are my children!" This expression gives them a feeling of security, worth and a feeling of belonging. That is, they feel safe roaming the world because they know who owns them. In addition, it also provides the firmness and pride in the feelings of children, because they feel possessed and prevent them from feeling rejected.

Family recognition of their children also communicates many things to the family itself. When we say to our children, "You are my child." That means we are declaring that we want to invest a large part of our self-esteem and happiness in the growth of our children. In other words, this means that sometimes we are willing to be embarrassed by our children. In addition, family recognition of their children also means an awareness of a family's responsibility for the lives of their children. That is, whatever happens in the lives of their children, the family must endure obligations and accompany them.

The family's commitment to their children is not just recognizing them as our children, but also a choice to be a parent for our children and a decision to work for the benefit of our children. So, commitment is not only an impulse from our hearts in the form of will, but also an outward expression in the form of action.

Our commitment to our children needs to be strengthened so that we can survive in all situations and conditions of our children. Strengthening these commitments can be achieved through our togetherness with our children. In this togetherness, we can tell our childhood, help our children's difficulties, and express our commitment to them. All this can strengthen our commitment to them and strengthen our relationship with them.

\section{Getting to Know Children}

In the association between human beings there is a saying that states, "do not know then do not love." This proverb states, how can we love someone if we do not know him well. So it is with our relationships with our children. Families that have lived for many years may not necessarily know their children and lives well. Family recognition of their children not only knows the name of the child, but also concerns the whole personality of the child, be it a hobby, likes, strengths or weaknesses.

Families can be said to know their children well if they recognize the abilities of children at a certain age, their needs for healthy growth, emotional stability, intellectual development, as well as personal preferences, abilities and support each unique characteristic of a child. In addition, families also need to recognize the spiritual needs and spiritual development of their children by providing time to accompany them both in prayer and in Bible reading.

Getting to know the child well certainly can not be done in one or two years, but it requires a long time, even spending all the time together with family children. In addition, this also requires patience, a strong will and includes the learning process in it. In other words, getting to know a child requires a continuous process of family togetherness with his child.

Getting to know the child properly is really needed in building dynamic friendships with our children. However, on the other hand we also need to pay attention to its excesses, because it must be recognized that a good introduction to our children can result in a tendency to be over protective so as to disturb their privacy. To anticipate this, a balance is needed so that our recognition of children does not make us behave like that.

\section{E. Consistency}

Family consistency with children includes: consistency in personality, behavior, promises and time. Personal consistency involves mastering the mood. A family that is consistently personal will not show anger in one minute and affection in the next without reason for changing moods.

Consistency in behavior means conformity in words and actions. In other words, the application of learning by doing in togetherness with their children. This results in children being able to do what is taught by the family because they have seen firsthand how the family has done it first.

In addition, the family must also be consistent in every promise. The family should avoid themselves from unreliable promises to their children because it can lead to a loss of trust, authority as a family for their children. Not only that, because an inconsistent family can cause a child to be hurt or discouraged (cf. Col. 3:21, "Fathers, do not offend your children so that they do not lose heart").

It is never too late to improve our consistency. Consistency improvement can be achieved through good scheduling and there is always a schedule available for families. In addition, we can also develop hobbies or mutual preferences so that there is enough time to be together with children. In addition, we also need to avoid haste and the most important thing is to instill in us to always learn to keep promises.

\section{F. Family and the Environment}

Dr. Dolores Durkin, an education expert at the University of Illinois, studies children who learn to read before they enter first grade in elementary school. And the result is that more than half come from "low" class families, a quarter are from "low" families and only a few from middle class families. Why is that? It turns out that parents who come from higher socioeconomic classes hold the theory that only trained teachers can teach reading and that parents should not interfere. Whereas families who are not familiar with this 
theory are happy to answer their children's questions about letters or words and want to help their children learn to read. It appears that children's intelligence develops better when the atmosphere in a family is warm and democratic.

So, it is clear that the main fact that greatly influences a child's personality is the family environment. Therefore the family environment must be conditioned so that it is conducive to the process of development and growth of children. Physical contact, tenderness, sincere care, attention that really helps the lives of children.

To build a prosperous society, improvement and serious differences in family conditions are needed, because the situation for the future depends on the attitude, acceptance and treatment of parents towards their children. Reorganize the family inclusive because it is in a very rapid development in the era of globalization as the era that is most vulnerable and full of changes in values and tensions that cause human beings into serious conflicts.

Towards modern parents with the process of globalization seems to increasingly eliminate the warmth of the relationship between individuals in the middle of the family. Father and mother increasingly busy chasing material, their children are busy with their business. Husband and wife relations, mother and father are increasingly loose and increasingly disappear.

The family becomes the foundation of hope to realize the peace and harmony of all that is in the family. The warmth of the family can be realized if there is a harmonious relationship, mutual respect and harmony in the existing family life.

\section{G. Build a Family}

In fact, parents really have the opportunity to influence children's intelligence (intellectual, emotional, moral, social and spiritual). In fact the role of parents is very likely to teach these various intelligences. In harmony with the time and sensitive period of children. Truly parents become a place of learning for them. Should not parents who know the most appropriate time and way of learning for their children. Thus, family institutions are the first education for emotional learning. ${ }^{10}$

Learning in the family other than through things that are said directly also in the form of examples from parents. When handling their own feelings and when dealing with others. John Gottman and Carole Horven of the University of Washington (1986) stated a family study consisting of a mother father and a chilid aged 4-5 years at Champion Illinois, concluded that children who received emotional training from parents would be better in academics., social skills, emotional and physical well-being.

Social science also proves that children who behave socially or maliciously generally have problems in the family environment (disputes, violence, indifference to parents) but adolescents who have good emotional relationships with their parents will be much more and not easily panic when faced with various kinds of problems.

The emotional atmosphere of the house that is conducive will also stimulate children to learn and develop their intelligence abilities and vice versa. In the experience that occurs when children who live in an atmosphere of parents who are always hostile, indifferent, and restrict their movements, it turns out IQ deteriorates. But, if at home their parents are warm, loving will give the child the opportunity to make decisions in the questions asked and also strongly support his IQ.

The role of parents towards children is very important in realizing love for their children.

Family planning (Family Planning) can be recommended to limit the number of children, because every family passively longs for their children to become people. Similar married couples are willing to sacrifice anything that is considered not to deviate from religious norms. For example career women who work hard. ${ }^{11}$

Having lots of children attention to 2 each child can be neglected and abandoned. With the increasing challenges and problems of the warmth of the household, especially when many children many families feel stressed in dealing with their children, so many mothers easily "angry" so that their children become targets.

\section{H. Be a friend to him}

Parents must be the best friends of children. If parents strengthen the foundation of friendship, "children's confidence in parents is very high especially if it is fostered consistently. Love a variety of feelings (tells about the contents of the heart), involvement and partiality to them in everything. And this will eliminate all the bitter roots in communication. As parents we must be on the side of the children so that sincere trust and life processes exist. For example a child who is experiencing pressure from outsiders (school, workplace) but he has a strong and firm foundation for his parents that the parents who are on his side as true friends to support him, then he can appreciate all with a strong trust.

\section{Exemplary}

Christ is an example of us parents and we are also an example to the needs of our children. A child builds his personality always trying to find an example to emulate in forming his personality. And the qualities taught by parents are good examples for children. Usually parents for children are heroes. Parental behavior is used as a measure for children to look for the child's characteristics. ${ }^{12}$

\section{J. Family Discipline}

Minggoes Tahiti and Diana carried out 3 rules of sin that their children must obey: First, there are things that should not be done at all, for example staying at a friend's house the reason for returning home late. Second, allowed with permission, for example watching, to the Mall but with permission. Third, there are things that must be explained from anywhere or anywhere.

It has been instilled since childhood to them so that even though they are far away (living in the US) they can still control themselves. They do not dare to break them because they have been implanted since childhood. Disciplining our children is important as an exercise for children in carrying out daily activities with extraordinary goals and results for broad-scale guidance through an organized life.

\section{K. Spiritual Supplies}

We live in an age of sophisticated technology with rapid changes in all fields. These changes lead to shifts in ethical, moral and cultural values. Consumerism, materialism, free sex have colored the lives of this age.

The speed and complexity of our modern world negatively impacts the spirituality and harmony of the family. Cultural pressures and the disproportionate loss of normative values 
require families to be vigilant and wise, as the Apostle Paul revealed in Ephesians 5: 15-16, "therefore, pay close attention, how you live, do not be like fools., but like the wise, and use the time available, because these days are evil."

Based on this phenomenon, the family must pay attention and meet the spiritual needs of their children. In this connection, a father should pay attention to the spiritual development of his children which varies according to the development of his age. In this connection, a father can learn more about this from the presentation of Piaget's theory of the 'stages of Cognitive development' related to Spiritual Development.

In order to pay attention and fulfill the spiritual needs of children, we must first equip ourselves with adequate spiritual provisions. This can be achieved if we grow in faith and maturity as someone who believes in Jesus Christ. In addition, the family must also involve God the Holy Spirit both in his personal life and togetherness with children, because the Holy Spirit is a Helper who will be with us forever ... and will teach everything ... and remind ... all that Jesus has said (John 14: 16, 26).

Families with their members can pray together, read and study the Bible together, praise and worship God together. Application of things like this is a manifestation of God's commandment in Deuteronomy 6: 5-7: "Love the Lord your God with all your heart and with all your soul and with all your strength ... you must teach it over and over to your children and talk about it when you you sit in your house, when you are on your way, when you lie down and when you wake up.

\section{Quiet Time}

When the family quiet is very necessary and made a pleasant habit. Adjust the quiet time so that it can be followed by children. Not too long and long-winded still hit the lives of children and in everyday life. When the quiet is done it becomes a common need. Ask the child what needs to be prayed for, and what he will do. If children can do it, the results will surely be enjoyed by our children to prosper life day to day.

\section{CONCLUSION}

Seeing children grow into our friends is a true joy for us as parents. This joy can be enjoyed if we try to build a harmonious family life. A harmonious family can be established dynamically if we base our family building on the basis of a strong spirituality accompanied by the fabric of good communication between us and our children. Marriage counseling is counseling held as an educational method, a method of reducing emotional tension, a method of helping married partners to solve problems and how to determine a better problem solving pattern. The problem of family relations needs to be dealt with properly and effectively, through therapeutic models and techniques. One therapy effort that can be done with marriage counseling.

Divorcement is a very unwanted event for every couple and family. Divorcement that occurred caused a lot of unpleasant things and pain that was felt by all parties, including both partners, children, and the two extended families of the couple. There are many factors that require couples to separate or divorce. One reason for divorced couples is a communication problem. 
European Journal of Theology and Philosophy

www.ej-theology.org

\section{NOTE}

\footnotetext{
${ }^{1}$ AIDS is a deadly venereal disease. For this reason, avoid extramarital sexual relations or marriage (prostitution, promiscuity, and same-sex or homosexual sexual relations). This disease is deadly because until now no cure has been found.

${ }^{2}$ Today in the US there are 4 main killers, namely: heart disease, cancer, accidents and suicide. In 2000 AIDS was ranked first for heart disease.

${ }^{3}$ Voice of Renewal, June 1, 19

${ }^{4}$ Kompas, 4 October 2019

${ }^{5}$ Kompas, 12 December 2019.

${ }^{6}$ Kompas, 9 August 1919.

${ }^{7}$ Kompas, October 1, 1919.

${ }^{8}$ V. Gilbert Beers, Parents Talk to Your Children! (Bandung: Kalam Hidup Foundation, 1997) 15

${ }^{9}$ Ken R. Canfield, 7 Secrets of being an Effective Father (Yogyakarta: Andi Foundation, 1977) 259.

${ }^{10}$ Daniel Soleman, Emotional Intelellegence (Jakarta: Gramedia, 1995).

11 "Minggoes Tahiti and Diana Nasution", Harmoni Vol. V / 14 (2001).

${ }^{12}$ Piaget's Theory of Stages of Cognitive Development related to Spiritual Development, as follows: (1) Motorsensory Stage (under the age of 2 years) Hold this has the characteristics: the understanding of God is still vague and associated with parents, prayer can provide comfort and deepen the bond between parent, child and God, requires a loving and warm environment, not yet fully aware of conscience. (2) Preoperational Stage (ages 2-7 years). Characteristics at this stage: God is depicted by highlighting the physical features of humans, the meaning of prayer is still blurred, able to understand Bible stories that are simple so that they need props, conscience starts to clear, evaluating right and wrong as absolute and the area of spiritual growth is the formation of attitudes toward God, the Bible and the church. (3) Formal and Abstract Operational Stage (over the age of 12 years): These stages have the characteristics of: seeing God as a close friend, a person who can be trusted completely, focusing on the attributes of God (mercy, omnipresence, omnipotent and omniscient), prayer is a conversation with God in person.
} 